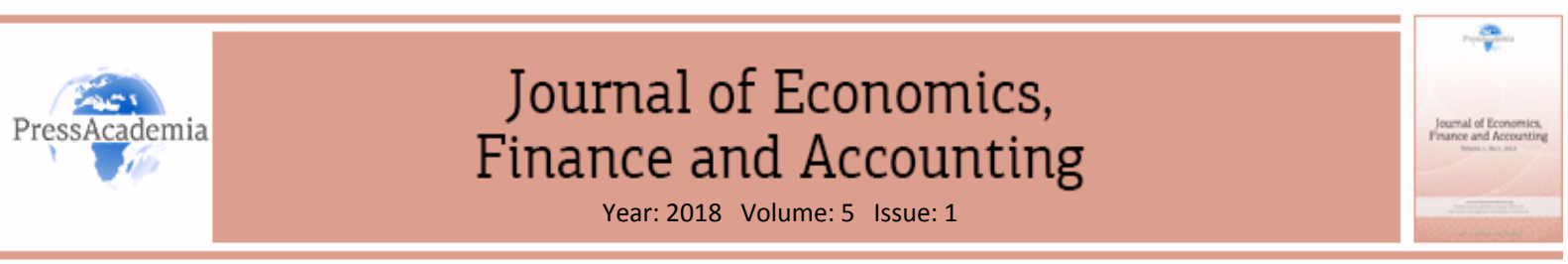

\title{
THE EFFECT OF ANNUAL REPORT READABILITY ON FINANCIAL ANALYSTS'BEHAVIOR
}

\author{
DOI: 10.17261/Pressacademia.2018.782 \\ JEFA- V.5-ISS.1-2018(4)-p.26-37
}

\author{
Ajina Aymen ${ }^{1}$, Ben Saad Sourour ${ }^{2}$, Msolli Badreddine ${ }^{3}$ \\ ${ }^{1}$ Arab East Colleges Riyadh and FSEG-University of Sousse, Tunisia, Rue 2 mars 1934-5012,Monastir, Tunisia, \\ ayman.ajina@gmail.com, ORCID: 0000-0003-0119-4612 \\ 2IHEC University of Sousse-Tunisia, Rue 2 mars 1934-501, Monastir, Tunisia. \\ bensaadsourour@yahoo.fr, ORCID: 0000-0002-7627-1363 \\ ${ }^{3}$ ESSCA School of Management, LUNAM University, France, 5 Rue de CondéCS 11030-33081 Bordeaux Cedex, \\ Badreddine.MSOLLI@essca.fr, ORCID: 0000-0003-0011-5302
}

To cite this document

Aymen, A., Sourour, B.S., Badreddine, M.,(2018). The effect of annual report readability on financial analysts' behaviour. Journal of Economics, Finance and Accounting (JEFA), V.5(1), p.26-37.

Permemant link to this document: http://doi.org/10.17261/Pressacademia.2018.782

Copyright: Published by PressAcademia and limited licenced re-use rights only.

\begin{abstract}
Purpose-This article examines a little investigated issue in France concerning the effect of the readability of financial information upon the behavior of financial analysts. We investigate 88 companies listed on the French CAC All between 2009 and 2014 . Readable annual reports are those that provide homogeneous, simple, clear, readable information that is understandable by all investors.

Methodology -We investigate 88 companies listed on the French CAC All between 2009 and 2014. Readable annual reports are those that provide homogeneous, simple, clear, readable information that is understandable by all investors. To measure readability, we use the Gunning Fog index and the Flesh Reading Ease formula. Results indicate a positive relation between analyst following and the readability of the annual reports. Furthermore, the number of financial analysts corresponds to the increasing attention paid by institutional investors to companies.

Findings- Readability reduces the agency costs and information asymmetry between investors, which attracts financial analysts, thus confirming the assumption of adverse selection.

Conclusion-French companies need to issue understandable information to the markets; this would imply using short sentences, common words, or the active voice. The aim of such strategies is to reduce the cognitive distance between information senders and users.
\end{abstract}

Keywords: Annual report readability, financial analysts, Gunning Fog index, Flesh Reading Ease formula, French stock market. JEL Codes: G30, G32, G34

\section{INTRODUCTION}

Transparent information helps maintain the equilibrium of financial markets, and the proliferation of financial scandals has highlighted its significance. Only a good communication policy can ensure a relationship of trust between companies and their stakeholders. Hence, the French New Economic Regulations (NRE) Act of 2001 has triggered intensified regulations and recommendations to enhance the readability of information issued in the context of financial reporting that has evolved in order to protect shareholders by ensuring accurate, specific, and truth ful information (Financial Security Act of August 1, 2003).

The French Financial Markets Authority (AMF) (2009) annual report emphasized the notion of readability. It issued an action plan to meet the crisis of public confidence and politicians' expectations. It also aimed to improve the readability of the financial information provided to "non-professional users". Government accounts are also subject to an obligation of readability. The organic law concerning finance laws (LOFT) imposes on the State the responsibility to submit "reliable, readable, and usable" information and specifies that usable information is that which can be understood by nonaccountants.

Readability studies of text corpora appeared in the 1940s in the United States and involved formulae designed to evaluate the degree of difficulty in reading texts based upon both lexical and morphosyntactic variables and typographical variables. Fernbach (1990) defines readability as the ease with which a text can be read quickly, understood, and memorized. 
Studies have investigated how easy it is to read annual reports and their components. Findings show that company annual reports are extremely hard to read; hence, they can be said to belong to a type of text that is likely to be inaccessible, particularly at the expense of a large number of inexperienced shareholders (Jones and Shoemaker, 1994). Consequently, the complexity of annual reports reinforces the information asymmetry between managers and investors and produces agency conflicts. Studies have also sought to determine whether annual reports have become more difficult to read over time, with mixed results (Jones and Shoemaker, 1994).

The readability of annual reports enhances the quality of information and helps ensure that the needs of both internal and external users of financial statements are met. Hence, the readable information provided by managers may appeal to analysts, reduce the time they spend understanding and interpreting this information, and facilitate their forecasts. It is thus necessary that the markets receive readable information, through reducing technical jargon and producing texts that can be understood by a large portion of the population. Francophone authorities believe that these measures would assist financial markets. Should this be the case, there would be a relationship between readable information and the behavior of financial analysts.

Financial analysts play a crucial role in the creation of the stock market value of companies. Studies have stressed the significance of analysts' recommendations and their influence upon investors' decisions and behavior (Ivkovicand Jegadeesh, 2004; Asquith et al., 2005). The benefits analysts bring stem potentially from two sources: finding private information and interpreting public information. These actors play a key role as intermediaries between companies and their partners (Schipper, 1991). Investors do not all possess the expertise or time needed to follow companies closely. The information provided by managers may facilitate the analysts' forecasts and reduce the time they spend finding information; hence, that information must be readable.

The relationship between information readability and analysts' behavior is therefore worth investigating from a dual perspective. First, to our knowledge, the present study is the first to investigate the relation between the readability of financial information and the behavior of financial analysts in France, as most of the studies concerning readability emanate from the Anglo-Saxon world. It is thus worth examining the readability of the corporate financial reporting of companies listed on the French stock market. Second, the study explores the complexity of financial information, based upon the textual contents of annual reports ${ }^{1}$, characterized by information asymmetries revealed through financial analyst following.

Few studies have investigated the impact of financial reporting upon analysts' following (Lang et Lundholm, 1996; Hope, 2003; Lakhal, 2009; Ajina et al, 2013). The first purpose of this study is to determine to what extent the readability of annual reports is significant for analysts and attracts them. The second purpose is to assess to what extent managers use the clarity of financial information to meet the information asymmetries existing in the markets and revealed through analyst following. The study findings show a positive relationship between analyst following and the readability of annual reports, which confirms the hypothesis of adverse selection. We also show that the number of financial analysts is related to the increasing attention institutional investors pay companies.

This paper is organized as follows: the second section examines the relation between the readability of annual reports and analyst following. The third section presents the sample and the research methodology, followed by the results and discussions of results. The final section concludes the paper.

\section{THE RELATION BETWEEN THE READABILITY OF ANNUAL REPORTS AND THE BEHAVIOR OF FINANCIAL ANALYSTS}

The resources made available to them and the authority to release findings that may alter the share prices of the companies they analyze give financial analysts the power to sanction any adverse observation regarding a company, in particular concerning information deemed inaccurate. The review of the literature on this issue shows that analysts influence significantly the behavior of investors. Managers consider that analysts are among the most important actors affecting their company share prices (Graham et al., 2005; Agrawal and Chen, 2012; Hugonand Muslu, 2010). Healy and Palepu (2001) suggest that information intermediaries such as analysts and rating agencies are involved in the private disclosure of information that helps detect poor management.

We review the literature concerning the quality of financial information through the lenses of three theories. First, the work of Akerlof (1970) shows the existence of information asymmetry, partly intended by the stakeholders in any transaction since each party modifies the information given to the other party in order to obtain greater benefits. The second construct is the theory of agency, as developed by Jensen and Meckling (1976). According to this theory, shareholders give managers a mandate for management in expectation that actions and performance will be transparent. However, in their annual report, the managers disclose only favorable elements, and they hide the unfavorable aspects. This observation, then, leads

${ }^{1}$ Annual reports are the visiting cards of companies; these exhaustive, economic, legal, accounting, and institutional documents provide information to all the groups dealing with the companies, and they reflect the companies' institutional image (Rogers and Grant 1997). 
to the assumption of managerial opportunism (Demsetzand Lehn, 1985).Jensen and Meckling (1976) argue that "to the extent that security analysis activities reduce the agency costs associated with the separation of ownershipand control, they are indeed socially productive" ( $p$ 68). From the perspective of these two theories, information disclosure by companies is a necessary and effective process to protect the shareholders against the managers' discretionary control and, indirectly, the minority shareholders against the risk of expropriation by the majority shareholders (Jensen and Meckling, 1976). Third, we use the positive accounting theory developed by Watts and Zimmerman $(1986,1990)$, which shows that the accounting documents that are issued can be manipulated, even non fraudulently, and are highly likely to influence investors' opinions.

Research in the domain of financial information quality is based upon these three theories, which have also generated a more open research trend that integrates linguistic dimensions with a view to making sense of the information provided in written documents. In theory, the effectiveness of financial reporting rests upon annual reports that facilitate reading and interpreting financial information. The notion of readability is a linguistic concept based upon several theoretical assumptions (e.g., text structure, writing style, and way of presenting information). The linguistic quality of annual reports thus supports the credibility, legitimacy, and quality of corporate governance. These theoretical assumptions then clearly call into question the transparency all the guides of good governance request but that remains an ideal. In the context of financial markets, these phenomena increase the information gap between the companies, on the one hand, and the stakeholders on the other. Using information intermediaries, as Healy and Palepu (2001) suggest, should partly solve the problem by facilitating information processing and flow.

According to Asquith et al. (2005), financial analysts are significant information intermediaries in financial markets. Several studies on this issue have shown that the usefulness of the analyst function potentially arises from two sources: finding private information and interpreting public information. The number of financial analysts who follow a firm is a variable often used to consider information asymmetry. Some authors suggest that information asymmetry is the main determining factor of the number of financial analysts who follow the firm (Chung et al., 1995; Van Ness et al., 2001). Others believe that the number of analysts strongly influences the level of information asymmetry that characterizes share prices. Hence, they suggest that the number of financial analysts who follow a firm be used as a measure of the information asymmetry relating to this firm (Roulstone, 2003).

The relation that exists between the number of financial analysts and the readability of annual reports is theoretically extremely complex because of the issue of supply and demand for analyst services (Hope, 2003). Bhushan (1989) proposes two ways of interpreting this relation between the readability of annual reports and analyst following. The first depends upon the demand for analyst services and the second upon the supply of analyst services to investors; the intersection of the supply and demand curves determines equilibrium.

First, complex annual reports are those that give unreadable information (Ajina et al, 2016), with a syntactic complexity that increases the processing and interpreting cost and, ultimately, the demand for analyst services. Analyst following becomes more important and, in fact, crucial, because it determines investors' decision making, particularly when the cost of the financial analysts' report is lower than that of processing the annual reports of the firms involved. Second, the cost of analyst following could increase because of the complexity of annual reports. In other words, analysts could bear both the cost of processing and interpreting unreadable information and the cost of finding private information. Such a situation could lead to less accurate forecasting. In the event of significant costs, the analyst following would be lower for companies with complex annual reports (Lehavy et al., 2011).

In sum, the readability level of annual reports increases the supply of analyst services. However, this level may increase or reduce the demand for analyst services in terms of the analysts' role in the market. Hence, the net effect depends upon the relative significance of this role, which is theoretically ambiguous. The issue is to determine whether the readability of financial reporting and analyst following are substitutes or complements.

Empirical research has focused upon the link between the number of financial analysts and the financial information reporting policy, in particular through the work of Lang and Lundholm (1996), Lakhal (2011), and Ajina et al. (2013). Lang and Lundholm (1996) assert that the positive link between the information disclosure index and the number of analysts following a firm stems from the fact that more information engenders a greater need for investors' interpretation and processing and later, for analyst services. Lakhal (2011) investigates the relations between the voluntary reporting of performance and financial analysts' behavior in a sample of 154 French companies over the 1998-2000 period. The study goal is twofold; first, it is to determine whether voluntary performance reporting is important to analysts and second, whether managers use voluntary reporting to reduce the information asymmetry present on the market. Study findings confirm the hypothesis that analysts are more inclined to follow the firms that regularly report performance information on the market. This conclusion entails that in response to firms' good reputation regarding financial reporting; analysts offer their services in order to reduce the costs of searching for private information. Lakhal (2011) thus asserts that voluntary performance reporting is an essential determining factor of analyst following. Ajina et al. (2013) confirm this finding and 
show a positive relation between the extent of the disclosure and the number of financial analysts in a sample of 189 French companies over the 2007-2011 period.

The most recent study is that of Ajina et al. (2015), who aim to investigate the relation between the governance index and analyst following in a sample of 174 French companies listed in the SBF 250 index over a four-year period (2008-2011). Findings show a positive relation between the number of analysts and the governance score, which indicates that analysts follow the firms that adopt governance mechanisms and provide quality reporting. Other authors examine the impact of new information upon share prices (Healy etal.2004) and the relation between analysts' behavior and sector information (Botosan and Harris, 2000) or the importance of intangible assets (Barth et al.,2001). All these studies conclude there is a positive relation between the quality of reporting and the financial analysts' activity. These studies, however, focus mainly upon one feature of reporting, namely the selection of an accounting option and the tax rate, and they do not include the effects related to the contents or the form of the other documents published with the document under investigation.

From a sample of 33,704 observations of companies listed in the United States between 1995 and 2006, Lehavy et al. (2011) note that the poor readability of annual reports increases the cost of document analysis and thus the demand for analyst services. The authors also show that analysts take longer to present their first forecast when the annual report is less readable. Finally, they indicate that less readable reports are associated with greater dispersion and lower accuracy than those of other firms. This uncertainty on the part of analysts increases with the low readability index score. In another study, Lang et al. (2004) use a sample of over 2,500 companies from 27 countries and assert that analysts are less likely to follow companies showing a greater risk of fraud or lack of transparency. These findings suggest that corporate governance plays an important role in analysts' willingness to follow companies and that increased analyst following is associated with higher valuations, particularly for firms likely to face governance problems.

Based upon the previous observations, we propose the following hypothesis:

There is a positive impact of Annual Report Readability on financial analyst following.

\section{SAMPLE AND METHODOLOGY}

\subsection{Data}

Initially, our sample included all the French companies listed on the CAC AllTradable index over a six-year period (20092014). After excluding the financial companies, since these are subject to specific legislation regarding reporting, and because of the non-availability of data relating to the number of financial analysts, our final sample included 88 companies and 528 observations. The financial data were extracted from the Datastream database. The data relating to the number of financial analysts were extracted from the $\mathrm{I} / \mathrm{B} / \mathrm{E} / \mathrm{S}$. database. To assess readability, we calculated a readability index from company annual reports that appeared to be a preferred communication tool with the public. These reports were obtained directly from the companies. Then, we converted these reports from a PDF to a Word format, and we eliminated tables and images. Finally, we used Textalyser to measure the readability of the reports produced by the companies in our sample.

\subsection{Presentation of the Variables}

\subsubsection{Financial Analyst Following}

In line with previous research (O'Brien and Bhushan, 1990; Brennan and Subrahmanyam, 1995), we define analyst following as the mean number of analysts following the firm. Financial analyst following is measured by the log of the number of financial analysts plus $1(\operatorname{Ln}(1+N A F))$.

\subsubsection{Annual Report Readability}

The reading scores, known as the "reading index", were originally based on primary school assessments. The application of these scores to annual reports dates back relatively far (Sydserff and Weetman, 2002) and drew a certain amount of criticism (Jones and Shoemaker, 1994). Estimating the validity of the formulae used is complex. Courtis (1997) asks the accounting researchers in communication to make greater effort to find a more formal approach for the validation of these formulae. Consequently, these scores are still in use and continue to show their efficiency as research tools. A reading index is a calculated score bound to standards defined by written texts classified in terms of reading difficulty. A reading index is a calculated score that varies between two extremes. At one end of the scale, there is very basic reading comprehension. At the other end, in contrast, reading comprehension is very advanced, corresponding essentially to scientific documents (Courtis, 1997). As in Li (2008), we assess the readability of annual reports using the Gunning-Fog Index and the Flesch Index derived from the computational linguistics literature. 
a-The Fog Index has been used widely and has seen increasing use in the accounting literature (Biddleet al., 2009; Miller, 2010; Lehavy et al., 2012; Lawrence, 2013; Ramanna and Watts, 2011).The Fog Index, developed by Gunning (1952), is a well-known and simple formula for measuring readability. Assuming that the text is well-written and logical, it captures text complexity as a function of syllables per word and wordsper sentence ${ }^{2}$. The index indicates the number of years of formal education a reader of average intelligence would need toread the text once and understand that piece of writing with its word-sentence workload. It is calculated as follows:

Fog $=($ words per sentence + percent of complex words $) \times 0.4$

Where complex words are defined as words with three syllables or more, the relation between the Fog and reading ease is as follows: FOGX18 means the text is unreadable; 14-18 (difficult); 12-14 (ideal); 10-12(acceptable); and 8-10 (childish).

b- The Flesh Reading Ease Formula is considered as one of the oldest and most accurate readability formulas. The Flesh Reading Ease Formula was developed by Flesh in 1948, and it is based on school texts covering Grades 3to 12 . The index is usually between 0 (hard) and 100 (easy). This orientation contrasts with some of the other readability measurements since higher scores mean easier reading. This test is often used to assess adult reading materials; it is used by the U.S. government agencies. Department of Defense as an indicator of readability. The specific mathematical formula is:

$$
\mathrm{FRE}=206.835-(1.015 \times \mathrm{ASL})-(84.6 \times \mathrm{ASW})
$$

FRE $=$ Readability Ease

$\mathbf{A S L}=$ Average Sentence Length (i.e., the number of words divided by the number of sentences)

ASW = Average number of syllables per word (i.e., the number of syllables divided by the number of words)

The output, i.e., RE is a number ranging from 0 to 100 . The higher the number, the easier the text is to read.

- Scores between 90.0 and 100.0 are considered easily understandable by an average 5th grader.

- Scores between 60.0 and 70.0 are considered easily understood by 8th and 9th graders.

- Scores between 0.0 and 30.0 are considered easily understood by college graduates.

\subsubsection{Control Variables}

Institutional investors - Institutional shareholders are able to perform monitoring activities on management, and this is considered as a positive signal sent to markets. Institutional investors are able to pay higher followingcosts to protect their assets (Shleifer and Vishny, 1988). As a result, they may encourage managers to take better accounting and financial decisions (Baker and Wallage, 2000). They are then considered as a governance mechanism, able to re-establish trust, guarantee information transparency, particularly in a country where investors' interests are less protected, as is the case in France (Ajina et al., 2015). Bhushan (1989) shows that analyst followingis associated with the increasing interest of institutional investors toward the firm. The authorfinds a positive relationship between institutional investors' ownership and analyst following on a sample of 1409 U.S.firms. Ackert and Athanassakos (2003) show that analysts respond to investors' demand for analysts' services to follow the firm.

Company size- The company size is measured through the logarithm of market capitalization at the year end. Company size is an important determinant of analyst following. This variable is justified from both a theoretical and an empirical perspective. Analysts seldom seek to follow small or medium-size companies.

Bhushan (1989) suggests that the demand for analysts' services is more pronounced for large firms. According to Lang and Lundholm (1996), large companies show better financial communication. They issue quality reporting, which facilitates analysts' forecasting and recommendations to their clients. Furthermore, Doukas et al. (2005) show that the number of financial analysts following a firm is more important for large firms. They suggest that the acquisition of information is costly for small firms. O'Brien and Bhushan (1990) acknowledge that large-size companies may be particularly important for analysts, which is confirmed by Ackert and Athanassakos (2003). An empirical study by Rajan and Servaes (1997) also shows that the earnings of large companies are more predictable than those of small companies. A positive relationship between company size and analyst following is thus to be expected.

\footnotetext{
${ }^{2}$ There are other popular measures of readability: the Kincaid index and the Flesch Reading Ease Index. The Kincaid Index, also referred to as the Flesch-Kincaid formula and calculated as (11.8_ syllables_per_word) + $(0.39$ _ words_per_sentence) _ $15: 59$, rates text by a U.S. grade school level. Therefore, a score of 8.0 means that the document could be understood by an average 8 th-gradestudent.
} 
Profitability - Empirical studies associate the level of coverage with profitability. Krische and Lee (2000) have introduced the market-to-book ratio among the determining factors of analyst following. These authors find that analysts give more favorable recommendations to performing stocks. Mc Nichols and O'Brien (1997) assert that analysts start by following the stocks they are optimistic about. Performing firms are the most transparent ones. We expect a positive relationship between profitability and analyst following.

Leverage- Debt ratio is measured as total liabilities divided by total assets. Through the lens of free cash flow theory, Jensen (1986) affirms that high indebtedness limits conflicts of interest between shareholders and managers through exerting pressure on the latter. Thus, highly indebted companies are more likely to communicate clearly (Palepu, 1986). Several studies have empirically demonstrated that the quality of company reporting is positively related to the companies' level of indebtedness (Xiao et al., 2004; Marston and Polei, 2004; Trabelsi, 2005). According to Hossain et al. (1994), highly indebted companies are more transparent than less indebted ones, given the monitoring carried out by their creditors. Hence, the more indebted companies show a low level of information asymmetry and high analyst following.

Business sector - The business sector may account for the varied analyst following. Bhushan (1989) argues that the business sector determines the growth prospects of companies and the analysts' cost of producing information. Furthermore, analysts are likely to prefer sectors with a large number of companies in order to benefit from economies of scale when collecting information (Hope, 2003). The business sector is a dummy variable that takes the value of 1 if the company is in the industrial sector and 0 if not.

\subsection{The model}

We used a panel regression analysis for a sample of 88companieslisted on the French CACALL index for a four-year period (2009-2014).Panel data analyses include two special dimensions: an individual dimension, as indicated by the $i$ index, standing for thecompany, and a t index standing for the period dimension (Gujarati, 2004). The Hausman test was used to choose between fixed effect and random effect models. The Hausman test compares the variance-covariance matrix of the two estimators:

$W=(\beta f-\beta a)^{\prime}[\operatorname{var}(\beta f-\beta a)]^{-1}(\beta f-\beta a)$

With: $\beta f$, fixed effects estimator and $\beta a$, random effects estimator. The result follows a chi- 2 with a $K-1$ of freedom. If the null hypothesis cannot be rejected, that is to say if the $p$-value is greater than the level of confidence, then the random effects that are effective are used. The results of the Hausman test, not reported here, show that the random effect model is preferable to the fixed effect. Our model is as follows:

$(\operatorname{Ln}(1+N A F))_{i t}=\alpha_{1}(F o g-\text { index })_{i t}+\alpha_{2} I N S T_{i t}+\alpha_{3} F_{S i z e_{i t}}+\alpha_{4} L e v_{i t}+\alpha_{5} R O A_{i t}+\alpha_{6} S E C T_{i t}+\varepsilon_{i t}$

$(\operatorname{Ln}(1+N A F))_{i t}=\alpha_{1}\left(F R E-\right.$ index $_{i t}+\alpha_{2} I N S T_{i t}+\alpha_{3} F S i z e_{i t}+\alpha_{4} L e v_{i t}+\alpha_{5} R O A_{i t}+\alpha_{6} S E C T_{i t}+\varepsilon_{i t}$

with:

Ln (NAF+1): Log of the number of financial analysts plus 1

Fog-index: Index of readability, denotes proxies for annual reports' readability level

FRE-index: Flesh Reading Ease index

INST: The percentage of shares held by institutional investors

FirmSize: The natural logarithm of total assets

Lev: The ratio of total debt to total assets

Profit: Net Income of the company divided by Total Assets

SECT: equals 1 if firm is in the industry, 0 otherwise

\section{RESULTS AND DISCUSSION}

\subsection{Descriptive Analysis}

Table 1 shows the sample statistics. The number of analysts following the companies in our sample is 18.38 on average and can reach the maximum value of 37. In the same context, Ajina et al (2015) find, in a sample of 174 French companies, a number of analysts varying between a minimum of 1 and a maximum of 56, with a median of 19 . Consequently, they assert that $50 \%$ of the companies have fewer than 19 analysts. In Hope's (2003) investigation of a sample of 20 countries, France is ranked 7th with an average number of 22.4 analysts for a sample of 72 French companies. The Netherlands come first 
with an average number of 29.5 analysts, followed by Germany with 28.8 analysts, Switzerland with 24.8, and Singapour, Spain, and Hong-Kong with respectively 23.4, 23.2, and 23.1 .

The mean value of the Fog Index is around 14.69. This value is close to that reported in Li (2008) for a sample of 55,719 firmyears with annual report filing dates between1994 and 2004, where the mean and median were 18.23 and 17.98 respectively; the value suggests that the companies' annual reports are, on average, difficult to read. Moreover, FOG displays a substantial cross sectional variation as evidenced in the standard deviation of 3.076. The minimum FRE score for the sample companies is 3.80 , and the maximum is 57 . Given that a higher FRE score indicates reading ease, and a score of 64 is considered as "plain English", the sample companies provide annual reports that can be described as easy to read.

The proportion of institutional investors in French companies is $18.21 \%$ on average, ranging from zero to $81.3 \%$, which shows that institutional investors are organizations that pool large sums of money invested in various French companies. The Net Income of the companies divided by Total Assets represents performance measure in the paper. Table 1 shows profitability as4.1601. The mean value of total debt on total assets ratio for the sample is 0.224 .

Table 1: Descriptive Statistics

\begin{tabular}{lccccc}
\hline & Mean & Median & $\begin{array}{c}\text { Standard } \\
\text { Deviation }\end{array}$ & Min & Max \\
\hline NAF & 18.384 & 13.165 & 161.485 & 0 & 37.17 \\
FOG & 16.820 & 16.5 & 3.096 & 10.8 & 24.1 \\
FRE & 38.2 & 42.2 & 5.135 & 3.8 & 57 \\
INST & 18.2134 & 27.84 & 23.236 & 0 & 81.3 \\
FSize & 6093.285 & 6558.16 & 11306.36 & 8.98 & 68565 \\
Lev & 0.224 & 0.252 & 0.321 & 0 & 0.97 \\
Profit & 4.1601 & 5.6 & 12.364 & 55 & -162.06 \\
SECT & 0.2973 & 1 & 0.457 & 0 & 1 \\
\hline
\end{tabular}

\subsection{Multivariate Analysis}

Table 2 shows a positive relation between the level of analyst following and the readability of annual reports. It thus appears that readability increases the number of financial analysts. The readability of the annual reports involves providing information that is homogeneous, simple, clear, readable, and understandable by all investors. Readability reduces agency costs and information asymmetry between investors, which attracts financial analysts, thus confirming the assumption of adverse selection. Furthermore, our findings do not support the assumption concerning transaction costs and are not in line with Bhushan's model (1989) and the results found by Lehavy et al. (2011). Hence, our findings confirm the assumption of complementarity between readability and analyst following.

French companies need to issue understandable information to the markets; this would imply using short sentences, common words, or the active voice. The aim of such strategies is to reduce the cognitive distance between information senders and users (Compin, 2004). Hence, readable reporting should be used to attract financial analysts. To analyze the robustness of our results, we used the Flesh Reading Ease index as a complementary measure of the readability of annual reports (see Model 2). This measure is an increasing function of readability. Hence, the higher the Flesh Reading Ease index, the more readable the annual reports are.

Table 2 also shows that Models 1 and 2 lead to nearly identical results regarding the relation between readability and analyst following. We show a positive relation between the Flesh Reading Ease index and analyst following, which confirms the hypothesis of adverse selection.

The presence of institutional investors in the capital structure of companies enhances the level of analyst following. The number of financial analysts corresponds to the increasing attention paid by institutional investors to companies. Hence, we confirm Ackert and Athanassakos' (2003) results. Institutional investors occupy long-term positions and have an active influence upon corporate management. They can censure managers through, for instance, putting pressure upon managers to adopt certain reforms, including those concerning the principles of corporate governance (Monks and Minow, 1995). Analysts seek to impose corporate governance rules designed to facilitate the control of companies in which they are shareholders. Their expectations concern mainly the transparency of information given to shareholders regarding companies' goals and practices, which influences positively the level of analyst following. 
In addition, findings show that the number of financial analysts increases with the company size. The company size coefficient is positive and significant at the threshold of $1 \%$, which shows that size is a primary determining factor of analyst following. This finding is in line with previous results of studies conducted in other countries by Lang and Lundholm (1996) and Lang et al.(2003) in the United States, Hope (2003) in an international context, Marston (1997) in Great Britain, and Lakhal (2011) in France.

The indebtedness coefficient shows a relation that is statistically non-significant and positive with the number of analysts. According to Hossain et al. (1994), highly indebted companies are more transparent than less indebted ones, on account of the monitoring carried out by their creditors. Hence, the more indebted companies show a low level of information asymmetry. We find a positive relation between performance and the number of financial analysts following companies. Analysts give more recommendations to over-valued stocks. This finding is in line with that of Mc Nichols and O'Brien (1997) who assert that analysts prefer to follow high performing stocks. Finally, we show the absence of a significant relation between the business sector and the number of analysts.

Table 2: Linear Regression

\begin{tabular}{|c|c|c|c|c|}
\hline \multirow[b]{2}{*}{ Variables } & \multicolumn{2}{|c|}{$\operatorname{Ln}(N A F+1)$} & \multicolumn{2}{|c|}{$\operatorname{Ln}(N A F+1)$} \\
\hline & Coefficient & t-statistic & Coefficient & t-statistic \\
\hline Cons & $0.583 * * *$ & 2.91 & $0.462 * * *$ & 3.51 \\
\hline LnFOG & $-0.136 * *$ & -2.23 & & \\
\hline LnFRE & & & $0.228 * * *$ & -3.21 \\
\hline INVINT & $0.106 * * *$ & 2.20 & $0.113^{* * *}$ & 2.19 \\
\hline FSize & $0.271 * * *$ & 11.63 & $0.193 * * *$ & 10.76 \\
\hline Lev & 0.103 & 0.152 & $0.261^{*}$ & 1.98 \\
\hline Profit & $0.032 * *$ & 2.23 & $0.065 * *$ & 2.26 \\
\hline SECT & -0.095 & -1.34 & -0.103 & -1.28 \\
\hline$R^{2}$ & \multicolumn{2}{|c|}{0.232} & \multicolumn{2}{|c|}{0.285} \\
\hline $\mathrm{Chi}^{2}$ & \multicolumn{2}{|c|}{$62.68(0.000)$} & \multicolumn{2}{|c|}{$65.63(0.000)$} \\
\hline
\end{tabular}

\section{CONCLUSION}

"If you can't understand a footnote or other managerial explanation, it's usually because the CEO doesn't want you to". Buffett, W. (2002).

This research study provides useful insights upon a little investigated issue in France relating to the effect of the readability of financial information upon the behavior of financial analysts (sell-side). We investigate 88 companies listed on the French CAC All between 2009 and 2014. We measure readability via the Gunning Fog index, one of the most well-known methods, named after its inventor Robert Gunning. Our second readability measure is the Flesh Reading Ease index, arising from computational linguistics, based upon the length of texts.

Our main findings indicate a positive relation between the analyst following level and the readability of annual reports, which implies that readability increases the number of financial analysts. The readability of annual reports involves providing information that is homogeneous, simple, clear, readable, and understandable by all investors. Readability reduces agency costs and information asymmetry between investors, which attracts financial analysts, thus confirming the assumption of adverse selection and the theory of complementarity between readability and analyst following. These results are confirmed by the Flesh Reading Ease index.

In addition, the presence of institutional investors in the capital structure of companies enhances the level of analyst following. The number of financial analysts corresponds to the increasing attention paid by institutional investors to companies. 
French companies need to issue understandable information to the markets; this would imply using short sentences, common words, or the active voice. The aim of such strategies is to reduce the cognitive distance between information senders and users. Hence, readable reporting should be used to attract financial analysts.

\section{REFERENCES}

Ackert, L., Athanassakos, G., 2003. A Simultaneous Equations Analysis of Analysts' Forecast Bias, Analyst Following, and Institutional Ownership. Journal of Business, Finance and Accounting, 30, n7-8, p. 10-17.

Ajina, A., Habib, A., Laouiti, M.,2013. Influence de la communication d'informations sur le comportement des analystes financiers en France. La Revue du Financier, Vol.35, 67-82.

Ajina A., El Houcine R., Saidani W., 2015. Corporate Governance and financial analysts' behavior in France. Revue Bancaire et Financière, Vol. 5, p. 377-384

Ajina A., Laouiti M., Msolli B., 2016. Guiding through the Fog: Does annual report readability reveal earnings management?. Research in International Business and Finance, Vol. 38, 509-516

Akerlof, G.A., 1970. The market for 'lemons': Quality uncertainty and the market mechanism. Quarterly Journal of Economics, Vol. 84(3), 488-500.

Asquith. P., Parag, A Pathakc., Jay, R Ritter., 2005. Short interest, institutional ownership, and stock returns. Journal of Financial Economics, Vol.78 (2005), 243-276.

Ball. R., 1992. The earnings price anomaly. Journal of Accounting and Economics, Vol.15, 2-3, 319-345.

Beaudet, C., 2001. Clarté, lisibilité, intelligibilité des textes: un état de la question et une proposition pédagogique. Recherches en rédaction professionnelle, Vol. 1(1), 1-17.

Beaver, W., 1968. The information content of annual earnings releases: A trading volume approach. Journal of Accounting Research, Supplement, 67-92.

Bhattacharya, N., Black, E.L., Christensen, T.E., Mergenthaler, R.D., 2004. Empirical evidence on recent trends in pro forma reporting. Accounting Horizons, Vol. 18(1), 27-43.

Bhushan, R., 1989. Firm characteristics and analyst following. Journal of Accounting and Economics, Vol. 11, p. 255-274.

Biddle, G. C., Hilary, G., Verdi, R. S., 2009. How does financial reporting quality relate to investment efficiency? Journal of Accounting and Economics. Vol 48, 2-3: 112-131

Björnsson, C.H., 1983. Readability of newspapers in 11 languages. Reading Research Quarterly, Vol. 18(4), pp. 480-497.

Bloomfield, R. J., 2002. The 'incomplete revelation hypothesis' and financial reporting. Accounting Horizons, Vol.16(3), 233-243.

Bourque, G., 1990. Des mesures de lisibilité. in Boyer, J.Y., Lebrun, M., (réd.). L'actualité de la recherche en lecture, Montréal, Association canadienne française pour l'avancement des sciences, p. 137-160.

Boyer, J.Y., 1992. La lisibilité. Revue française de pédagogie, Vol.99, 5-14.

Brad, B., Lehavy, R., Maureen, M.N., Brett, T., 2001.Can Investors Profit from the Prophets? Security Anlysis Recommandations and Stock Returns. The Journal of Finance, $\mathrm{n}^{\circ} 56$

Brad, B., Lehavy, R., Maureen, M.N., Brett, T., 2002. Profits and Losses: Reassessing the Returns to Analysts Stock Recommandations ». Research Paper $n^{\circ}$ 1692, Graduate School of Business, Stan ford University, May.

Brennan., Subrahmanyam, A., 1995. Investment analysis and price formation in securities markets. Journalof Financial Economics, Vol.38(3): 361-381.

Callen, J. L., Khan, M., Lu, H., 2009. Accounting quality, stock price delay and future stock returns. Working paper, University of Toronto and Massachusetts Institute of Technology.

Chomsky, N., 1976. Reflections on language. Temple Smith London.

Clatworthy, M., Jones, M.J., 2001.The Effect of Thematic Structure on the Variabilité of Annual Report Readability. Accounting, Auditing \& Accountability Journal, Vol. 14(3), pp. 311-326.

Cohen, D., 2005. Financial reporting quality: determinants and economic consequences. Working Paper, New York University.

Conquet, A., Richaudeau, F., 1973. Cinq methods de mesure de la lisibilité. Communication et Langages, $\mathrm{n}^{\circ} 17, \mathrm{pp}$. 5-16.

Courtis, J.K., 1986. An Investigation into Annual Report Readability and Corporate Risk Return Relationships. Accounting and Business Reasearch, Vol. 16(64), pp. 285-294. 
Courtis, J.K., 1987. Fry, Smog, Lix and Rix: insinuations about corporate business communications. Journal of Business Communication, spring, pp. 19-27.

Courtis, J.K., 1995. Readibility of annual reports: Western versus asian evidence. Accounting, Auditing, Accountability Journal, Vol. 8(2), 417

Cowles A., 1933. Can Stock Market Forecasters Forecast?. Econometrica, Volume 1, Issue 3, July.

Dale, E., Chall, J., 1948. A formula for predicting readability. Educational Research Bulletin 27.

Dechow, P.M., 1994. Accounting earnings and cash flows as measures of firm performance: The role of accounting accruals. Journal of Accounting and Economics, Vol. 18(1), 3-42.

Dechow, P., Ge, W., Schrand, C., 2010. Understanding earnings quality: A review of the proxies, their determinants and their consequences. Journal of Accounting and Economics, Vol. 50(2-3), 344-401.

De Landsheere, G., 1963. Pour une application des tests de lisibilite de flesch a la langue francaise. Travail Humain 26.

Desai, H., Liang, B., Singh, A., 2000. Do All-Stars Shine? Evaluation of Analyst Recommandations. Financial Analysts Journal,Volume LV I, n 3 ,May-June.

Ehrlich, M., Charles, A., Tardieu, H., 1992. La superstructure des textes ex positifs est-elle prise en charge lors de la sélection des informations importantes?. Le résumé de texte: 183-206.

Fama, E.F., 1970. Efficient capital markets: A review of theory and empirical work. The Journal of Finance, Vol. 25(2), 383-417.

Fama, E., 1991. Efficient Capital Markets: II. The Journal of Finance, Volume XL VI, Issue5, December.

Fernbach, N., 1990. La lisibilité dans la réaction juridique au Québec. Ottawa, Le Centre de promotion de la lisibilité, Centre Canadien d'information juridique.

Flesch, R., 1948. A new readability yardstick. Journal of Applied Psychology, Vol. 32(3), 221-233.

Flesch, R., 1974. The Art of Readable Writing, Harper \& Row, New York, NY, 1974.

Fontowicz, L., Garcia, M., 2000. L’impact informationnel des réunions d'information de la SFAF. Analyse financière, nº1 2 1, Janvier.

Francis, J., LaFond, R., Olsson, P., Schipper, K., 2005a. The market pricing of accruals quality. Journal of Accounting and Economics, Vol.2, 295-327.

Francis, J., Nanda, D., Olsson, P., 2005b. Voluntary disclosure, information quality, and costs of capital. Working Paper, Duke University.

Grossman, S.J.,Hart, O.D., 1980. Takeover bids, the free-rider problem, and the theory of the corporation. The Bell Journal of Economics, Vol.11(1), 42-64.

Gujarati, D.N., 2004. Économétrie. De Boeck Supérieur.

Gunning, R., 1952. The Technique of Clear Writing. McGraw-Hill, New York.

Hammami, H., 2003. Facilité de lecture des rapports annuels : Evaluation des informations comptables textuelles résultats préliminaires du context italien. Actes de l'Association

Francophone de Comptabilité (AFC), Orléans, 21p.

Harrison, C., 1980. Readability in the classroom. Cambridge University Press, Cambridge.

Healy, P.M., PALEPU, k.G., 2001. Information asymmetry, corporate disclosure and the capital markets: A review of the empirical disclosure literature. Journal of Accounting and Economics, Vol. 31, p. 405- 440.

Henry, G., 1975. Comment mesurer la lisibilité. Bruxelles, Labor / Paris, Fernand Nathan.

HOPE, K., THOMAS, W.B., WINTERBOTHAM, G., 2006. The Impact of Nondisclosure of Geographic Segment Earnings on Earnings Predictability, Journal of Accounting, Auditing \& Finance, p. 323- 347.

HOPE, O., 2003. Disclosure practices, enforcement of accounting standards and analysts'forecast accuracy: an international study. Journal of Accounting Research, Vol 41, p. 235-272.

Hope, O. K., 2003. Firm level disclosures and the relative roles of culture and legal origin. Journal of International Financial Management \& Accounting, 14:3, 218-48

Hrshleifer, D., Teoh, S.H., 2003. Limited attention, information disclosure, and financial reporting. Journal of Accounting and Economics, Vol. 36(1-3), 337-386.

Indjejikian, R. J., 1991. The impact of costly information interpretation on firm disclosure decisions. Journal of Accounting Research, Vol.29(2) : 277-301.

Lereboullet, J., 2000. Quelles places financières pour demain?. Revue d'économie financière, No. 57 : p. 157-160 
Jensen, M.C., Meckling, W.H., 1976. Theory of the firm: Managerial behavior, agency costs and ownership structure. Journal of Financial Economics, Vol. 3(4), 305-360.

Jones, M.J., 1988. A Longitudinal Study of the Readability of the Chairman's Narratives in the Corporate Reports of a UK Company. Accounting and Busines Research, Vol. 18(2), pp. 297-308.

Julien, L.M., 2015. La lisibilité de l'information financière. Revue française de linguistique appliquée 2015/2 (Vol. XX), p. 99-113.

Kandel, L., Moles, A., 1958. Application de l'Indice de Flesch à la langue française. Cahiers d'Études de Radio-Télévision, Flammarion, Paris, $\mathrm{n}^{\circ} 19$, p. $252-274$

Krische, S.D., Lee, C.M., 2000. The Information Content of Analyst Stock Recommendations. Working paper, Johnson Graduate School of Management, Cornell University

Klare, G.R., 1963. The measurement of Readability. lowa State University Press, lowa.

Labasse, B., 1999. La lisibilité rédactionnelle : Fondements et perspectives. Communication et langages 121 (1): 86-103.

Lang, M.H., Lundholm, R.J., 1996. Corporate disclosure policy and analyst behavior. Accounting Review, Vol. 71, p. 467-492.

Lang, M. H., Lins, K.V., Miller, D.P., 2003. ADRs, Analysts, and Accuracy: Does Cross-

Listing in the U.S. Improve of Firm's Information Environment and Increase Market Value?. Journal of Accounting Research, Vol.41, $\mathrm{n}^{\circ} 2$, $\mathrm{p}$. 317-345

Lang, M. H., Lins, K.V., Miller, D.P., 2004. Concentrated Control, Analyst Following, and Valuation: Do Analysts Matter Most when Investors are Protected Least?. Journal of Accounting Research, Vol.42, n³, p. 589-623

Lehavy, R., Feng, L., Merkley, K., 2011. The effect of annual report readability on analystfollowing and the properties of their earnings forecasts. Accounting Review, Vol. 86 (3): 1087-1115.

Lewis, N. R., Parker, L. D., Pound, G. D., Sutcliffe, P., 1986. Accounting Report

Readability: the Use of Readability Techniques. Accounting and Business Reasearch, Vol.16 (63), pp. 199-213.

Li, F., 2008. Annual report readability, current earnings, and earnings persistence. Journal of Accounting and Economics, 45-2/3, 221-247.

Loughran, T., McDonald, B., 2010. Measuring readability in financial text. Working paper, University of Notre Dame.

Marston, C., 1997. Firm characteristics and analyst following in the UK. The British Accounting Review, Vol. 29(4), 335-47.

McNichols, M.F., O'Brien, P.C., 1997. Self-selection and Analyst Coverage. Journal of Accounting Research, Vol.35, p. 167-199.

O’Brien, P., Bhushan, R., 1990. Analyst Following and Institutional Holding. Journal of Accounting Research, p. 55-76.

Pashalian, R., Crissy, J.E.W., 1950. How readable are corporate annual report?. Journal of Applied Psychology, Vol. 34(4), pp. 244-248.

Plumlee, M. A., 2003. The effect of information complexity on analysts' use of that information. The Accounting Review, Vol. 78(1): 275296.

Pound, G.D., 1981. A note on audit report readability. Accounting and Finance, May,pp. 45-55.

Previts, G. J., Bricker, R. J., Robinson, T. R., Young, S. J., 1994. A content analysis of sell-side financial analysts company reports. Accounting Horizons, Vol. 8(2): 55-70.

Rogers, R. K., Grant, J., 1997. Content analysis of information cited in reports of sell-side financial analysts. Journal of Financial Statement Analysis. Vol. 3(1): 17-30.

Ronald, A.D., Shyam, S., 2001. Why Not Allow FASB and IASB Standards to Compete in the U.S.?. Accounting Horizons: September 2001, Vol. 15, No. 3, pp. 257-271.

Schrand, C.M., Walther, B.R., 2000. Strategic benchmarks in earnings announcements: The selective disclosure of prior-period earnings components. Accounting Review, Vol. 75(2), 151-177.

Schipper, K., 1991. Analysts'forecasts. Accounting Horizons, Vol. 5, p. 105-131.

Schroder, N., GIBSON, C., 1990. Readability of Management's Discussion and Analysis. Accounting Horizons, Vol. 4, no 4, December: 78-87

Schroder, N., AGGARWAL, R., GIBSON, C., 1991. Financial Reporting by Japanese Firms on the NYSE: An Analysis of Linguistic Content. Management International Review, Vol.31 (3): 233-251.

Schroder, N., GIBSON, C., 1992. Are Summary Annual Reports Successful?. Accounting Horizons, Vol. 6(2), juin : 28-37.

Schroeder, M., 2002. SEC proposes rules to improve disclosure by public companies. Wall Street Journal_May 1_: C5.

SEC., 1998. A Plain English Handbook: How to Create Clear SEC Disclosure Documents. U.S. Securities and Exchange Commission, Washington, DC. 
Smith, J. E., Smith, N. P., 1971. Readability: a Measure of the Performance of the Communication Function of Financial Reporting. The Accounting Revieuw, Vol. 36(3), pp. 552-561.

Smith, M., Taffler, R., 1992a. The Chairman's Statement and Corporate Financial Performance. Accounting and Finance, Vol. 32(2), pp. 7590

Smith, M., Taffler, R., 1992b. Readability and Understandability:Different Measures of the Textual Complexity of Accounting Narrative . Accounting, Auditing \& Accountability Journal, Vol. 5(4), pp. 84-98.

Soper, F.J., Dolphin, R.J., 1964. Readability and Corporate Annual Reports. The Accounting Review, Vol. 39(2), pp. 358-362.

Sorin, N., 1996. De la lisibilité linguistique à une lisibilité sémiotique. Revue Québécoise de linguistique, Vol.25(1), 61-97.

Stevens, W.P., Stevens, K.C. Raabe, W.A., 1983. Communications in accounting: Readability of FASB statements. Review of Business and Economic Research, Vol.19 (1), 110-118.

Still, M.D., 1972. The Readability of Chairmen's Statements. Accounting and Business Research, Vol. 3(9), pp. 36-39.

Subbramanian, R., Insley, R. G., Blackwell, R. D., 1993. Performance andReadability: A Comparaison of Annual Reports of Profitable and Unprofitable Corporations. The Journal of Business Communication, vol. 30(1): 46-61.

Thorndike, E.L., 1921. The teacher's workbook, NY: Teacher's College, Columbia

University, New York.

VAN NESS, B. F., VAN NESS, R. A., RICHARD, S., 2001. How well do adverse selection components measure adverse selection?. FinancialManagement, Vol. 30, p. 77-98.

Watts, R.L., Zimmerman, J.L., 1986. Positive accounting theory. Englewood Cliffs, NJ, Prentice Hall.

Watts, R.L., Zimmerman, J.L., 1990. Positive accounting theory: A ten-year perspective. Accounting Review, Vol.65 (1), $131-156$.

Womack, K., 1996. Do Bokerage Analysts' Recommandations Have Investment Value?. The Journal of Finance, Volume LI, Issue 1, March.

You, H., Zhang, X., 2009. Financial reporting complexity and investor underreaction to 10-K information. Review of Accounting Studies, Vol.14 (4): 559-586

Zamanian, M., Heydari, P., 2012. Readability of Texts: State of the Art. Theory and Practice in Language Studies, Vol. 2(1), pp. 43-53. 